\title{
Remittitur Review: Constitutionality and Efficiency in Liquidated and Unliquidated Damage Cases
}

When a defendant considers a damage award to be excessive and moves for a new trial on that basis, federal trial court judges have long exercised the power to issue a remittitur, ordering the plaintiff either to accept a diminished award or to submit to a new trial. ${ }^{1}$ Traditionally, neither a remittitur order nor the trial judge's refusal to issue one was reviewable by an appellate court.

In the last two decades, the power of the federal courts to review has expanded greatly. Currently, the refusal to order a remittitur or new trial is reviewable for abuse of discretion in all eleven circuits; ${ }^{2}$ the Supreme Court, however, has repeatedly refused explicitly to acknowledge the legitimacy of appellate review in this area. ${ }^{3} \mathrm{Re}-$ viewability of remittitur orders, typically at the instance of a plaintiff who has accepted the remittitur "under protest," is just beginning to gain approval in the federal courts, most notably in the Fifth Circuit. ${ }^{4}$ But in this area as well, Supreme Court precedent seems to be against an extension of the power to review. ${ }^{5}$

The issue to be explored in this comment is whether and to what extent remittitur orders and the refusal to issue them should be reviewable. The first part of the comment sets forth the procedural and historical framework of the problem. The second part considers the apparent reason for the Supreme Court's reluctance to sanction reviewability, that is, its fear of infringing on the seventh amendment prohibition against reexamining facts found by a jury. Finally, the comment examines the desirability of review from the standpoint of judicial economy and integrity, concluding that remittitur review, while appropriate in some types of cases, can be

'See, e.g., Blunt v. Little, 3 F. Cas. 760 (No. 1578) (C.C.D. Mass. 1822), were Mr. Justice Story, sitting on circuit, authorized a remittitur as early as 1822 . See also Union Pac. R.R. v. Hadley, 246 U.S. 330 (1918); Gila Valley G. \& N. Ry. v. Hall, 232 U.S. 94 (1914); Tevis v. Ryan, 233 U.S. 273 (1914); German Alliance Ins. Co. v. Hale, 219 U.S. 307 (1911); Hansen v. Boyd, 161 U.S. 397 (1896); Clark v. Sidway, 142 U.S. 682 (1892); Arkansas Valley Land \& Cattle Co. v. Mann, 130 U.S. 69 (1889); Northern Pac. R.R. v. Herbert, 116 U.S. 642 (1886).

${ }^{2}$ See cases cited at note 22 infra.

${ }^{3}$ E.g., Gruenthal v. Long Island R.R., 393 U.S. 156 (1968); see text and notes at notes 35-44 infra.

- E.g., Steinberg v. Indemnity Ins. Co., 364 F.2d 266 (5th Cir. 1966).

5 Woodworth v. Chesbrough, 244 U.S. 79, 82 (1917); see Section IA infra. 
clearly unproductive-and perhaps even unconstitutional-in others.

\section{The Procedural and Historical Background}

\section{A. Reviewability of Remittitur Orders}

The right of a plaintiff to appeal a remittitur order was last considered by the Supreme Court in 1917, in Woodworth $v$. Chesbrough. ${ }^{6}$ Plaintiff Woodworth, suing the defendant for damages resulting from violations of the National Bank Act, suffered two appellate court reversals of favorable jury verdicts on the ground that the awards were excessive. On the second appeal, the circuit court gave Woodworth an opportunity to avoid a third trial by consenting to remit part of the second jury award. Woodworth consented to the remittitur under protest, solely for the purpose of obtaining a final judgment from which to appeal. The Supreme Court, however, frustrated Woodworth's strategy and held that he could not "retract" his acquiesence in the remittitur. Justice McKenna, writing for the Court, termed Woodworth's position "anomalous" in that he had

secured a judgment against Chesbrough and yet [seeks] to retract the condition upon which it was obtained. This he cannot do . . . . He encounters, besides, another obstacle: If the remittitur be disregarded the judgment entered upon it must be disregarded and the original judgment [awarding a new trial] restored, which, not being final, cannot be reviewed. ${ }^{\text {? }}$

The Woodworth case thus places the plaintiff in a dilemma: if he accepts a remittitur, he is not permitted to appeal it, but if he rejects the remittitur, a new trial order, which is non-final and hence non-reviewable as well, will be issued.

In applying the general rule that interlocutory orders are not reviewable, the Court failed to consider the special problems that arise in situations like Woodworth where, for all practical purposes, interim orders may become final dispositions. Since at present there seems to be no limit on the number of times a federal trial judge may order a new trial because of excessive damages, the practical effect of making an order directing a new trial unreviewable is to give the judge the absolute power to force the plaintiff onto a poten-

- 244 U.S. 79 (1917); see Koenigsberger v. Richmond Silver Mining Co., 158 U.S. 41 (1895); cf. Lewis v. Wilson, 151 U.S. 551 (1894); Kennon v. Gilmer, 131 U.S. 22 (1889).

7 Woodworth v. Chesbrough, 244 U.S. 79, 82 (1917). 
tially permanent treadmill, forever winning jury awards only to have them nullified by the court.

To get off this treadmill, the plaintiff needs a final judgment from which to appeal; ${ }^{8}$ consenting to a remittitur under protest would seem to offer an ideal escape. Yet it was precisely this route that the Woodworth Court chose to foreclose, finding the "anomalous" nature of the plaintiff's position too formidable an obstacle to overcome. In terms of traditional procedural concepts, the Court's position is difficult to understand. Because his consent was neither voluntary nor a consequence of laches, the plaintiff does not seem to have waived his right to appeal. And, so long as the plaintiff made it clear that he was consenting to remittitur only under protest, explicitly reserving his right to appeal, it would be impossible for any interested party to show that he had reasonably relied to his detriment on the plaintiff's acquiescence in the reduced award. Thus an estoppel theory would also seem inappropriate. ${ }^{9}$

Despite these difficulties, the Woodworth rule prevailed until recently in all eleven circuits. ${ }^{10}$ In 1963, however, the Fifth Circuit began to waiver in its support of the rule. ${ }^{11}$ In Delta Engineering

- There is no precedent permitting the plaintiff to take an interlocutory appeal of a new trial order under the Interlocutory Appeals Act, 28 U.S.C. $\$ 1292(\mathrm{~b})$ (1970). Appeal under the Act is discretionary and depends upon the trial judge being willing to characterize the order as involving "a controlling question of law."

- See Note, Appealability of Judgments Entered Pursuant to Remittiturs in Federal Courts, 1975 DukE L.J. 1150, 1156-57 [hereinafter cited as DukE Note]; Comment, Waiver of Right to Appeal, 39 NEB. L. REv. $739-56$ (1960). See also Comment, Civil Procedure-Remittitur-Remitting Parties' Right to Cross-Appeal, 49 N.C.L. REv. 141 (1970).

10 See, e.g., Collum v. Butler, 421 F.2d 1257 (7th Cir. 1970); Movible Offshore Co. v. Ousley, 346 F.2d 870 (5th Cir. 1965); S. Birch \& Sons v. Martin, 244 F.2d 556 (9th Cir.), cert. denied, 355 U.S. 837 (1957); Mattox v. News Syndicate Co., 176 F.2d 897 (2d Cir. 1949); Bristol Gas \& Elec. Co. v. Boy, 261 F. 297 (6th Cir. 1919). Remittitur orders were reviewable, if at all, only after a final judgment had been entered in a second trial, at which time an appeal made the entire record reviewable, including interlocutory orders such as the granting of defendant's motion for new trial after the plaintiff had rejected a conditional remittitur order. See, e.g., Reinertsen v. George W. Rogers Constr. Corp., 519 F.2d 531 (2d Cir. 1975); Taylor v. Washington Terminal Co., 409 F.2d 145 (D.C. Cir.), cert. denied, 396 U.S. 835 (1969).

11 Two other circuits have explicitly considered the Fifth Circuit's approach to remittitur review. The Seventh Circuit rejected it in Collum v. Butler, 421 F.2d 1257 (7th Cir. 1970), while the Second Circuit postponed its decision to another day in Reinertsen v. George W. Rogers Constr. Corp., 519 F.2d 531 (2d Cir. 1975).

The Sixth Circuit has taken a different tack, holding that, under Erie, state practice on remittitur review must be applied to federal diversity cases. See Mooney v. Henderson Portion Pack Co., 334 F.2d 7 (6th Cir. 1964), followed in Burnett v. Coleman Co., 507 F.2d 726 (6th Cir. 1974); Brewer v. Uniroyal, Inc., 498 F.2d 973 (6th Cir. 1974); Manning v. Altec, Inc., 488 F.2d 127 (6th Cir. 1973). In Mooney, the court based its result on the "outcome determination" test of Guaranty Trust Co. v. York, 326 U.S. 99 (1945), reasoning that since a litigant could obtain review of a remittitur accepted under protest in the state court, this opportunity 
Corp. v. Scott, ${ }^{12}$ the court assumed without deciding that it was possible for plaintiffs to challenge remittitur orders, so long as they had not "actually obtained the fruits of a judgment."13 Finding no abuse of discretion in the trial judge's remittitur order in the case before it, the court declined to reach the issue of power to review; it did, however, note that "it would be a strange rule that would keep a plaintiff from challenging the legal correctness of any action having such portentous consequences." 14

Three years later in Steinberg $v$. Indemnity Insurance Co., ${ }^{15}$ the Fifth Circuit found that the trial court had abused its discretion in ordering a remittitur. The plaintiff in that case had first attempted to skirt the waiver issue by appealing the remittitur order itself, without accepting or rejecting it. The Fifth Circuit initially refused to review on the ground that the order remained interlocutory. ${ }^{16}$ When, however, the plaintiff accepted the remittitur conditionally as a means to appeal, the court found that she had "suffered a sufficiently adverse adjudication to allow an appeal." They added that " $[\mathrm{m}]$ oreover, plaintiff has not collected the judgment as reduced."17

The Fifth Circuit did not cite Woodworth in either Delta Engineering or Steinberg. One might argue that both cases differed from Woodworth in that the plaintiffs in those cases had not "enjoyed the fruits" of remittitur, that is, had not actually collected the

must also be made available in the federal court. The Seventh Circuit rejected this reasoning in Dorin v. Equitable Life Assurance Soc'y, 382 F.2d 73 (7th Cir. 1967), holding that the outcome determination test could not be used without reference to the criteria set forth in Hanna v. Plumer, 380 U.S. 460 (1965). Finding that a difference in remittitur procedure, which comes into play only after a full trial has been held, would not encourage forumshopping or result in inequitable administration of the laws, the Seventh Circuit refused to hold the federal courts bound to state procedure in this regard. Cf. Reinertsen v. George W. Rogers Constr. Corp., 519 F.2d 531, 534 (2d Cir. 1975). See also DukE Note, supra note 9, at 1151-55.

Even apart from normal Erie considerations, it would seem improper to utilize state remittitur procedure in the federal courts. As will be argued below, the legitimacy of both remittitur and remittitur review is bound up with seventh amendment considerations. Since the seventh amendment does not apply to state court procedure, Pearson v. Yewdall, 95 U.S. 294 (1877), transference of state remittitur principles to the federal court could be unconstitutional in some respects. Furthermore, in diversity cases where federal courts apply state substantive law the seventh amendment nonetheless applies. Atlantic \& Gulf Stevedores, Inc. v. Ellerman Lines, Ltd., 369 U.S. 355, 359-60 (1962); Byrd v. Blue Ridge Cooperative, 356 U.S. $525,538-39$ (1958).

12322 F.2d 11 (1963).

is Id. at 15.

"Id.

15364 F.2d 266 (5th Cir. 1966).

Is Id. at 267 (noting unpublished order).

17 Id. at 268. 
reduced judgments they sought to overturn, whereas Woodworth apparently had. But in United States $v .1160 .96$ Acres of Land, ${ }^{18}$ the court was presented with a case in which even this tenuous distinction could not be made, since the plaintiffs had collected the reduced judgment and had still appealed the remittitur. And, this time, the defendants' protest that plaintiffs had waived their right to appeal was based squarely on Woodworth.

In response to this challenge, the Fifth Circuit attempted to draw a different distinction:

But Woodworth implies that the judgment creditor has a real choice between taking a sure sum and putting the case to another trial and that the only detriment suffered is the risk that on the conditionally ordered retrial, the recovery will be even less than the reduced amount of the remittitur. ${ }^{19}$

The suggestion here is that a plaintiff can appeal a remittitur order only when he did not freely choose to accept it. This distinction also appears untenable. So long as there is no limit to the number of retrials that may be ordered, it would seem that a plaintiff never has a real choice in a remittitur situation. Sooner or later, even the most determined plaintiff will have to get off the retrial treadmill, and the only way to do so is to consent to a remittitur or to its non-judicial equivalent, a settlement. In this sense, all remittiturs involve a forced instead of a free choice; indeed, the whole rationale behind the remittitur procedure is to pressure the plaintiff into taking less than that which a jury has awarded him.

The Fifth Circuit did not, however, rely heavily on this distinction. A few paragraphs later the court went on to conclude that "the right to maintain the appeal turns on whether the remittitur is accepted without protest." 20 Thus the court implicitly recognized that its case, though not its result, was identical to Woodworth. ${ }^{21} \mathrm{As}$

18432 F.2d 910 (5th Cir. 1970).

19 Id. at 912 (emphasis added).

${ }^{20} \mathrm{Id}$.

${ }^{21}$ In the DuKe Note, supra note 9, at 1159, it is argued that the Supreme Court has perhaps tacitly shifted its position on the remittitur question since Woodworth. Banks v. Chicago Grain Trimmers Ass'n, 390 U.S. 459 (1968), is cited as evidence of this change; that case, however, dealt with the wholly unrelated issue of whether acceptance of a remittitur constitutes a "compromise" with an injurer that discharges an employer from liability under the Longshoremen's and Harbor Worker's Compensation Act. Id. at 466-67. The Duke Note also argues that the Court's obvious uneasiness with remittitur in Dimick v. Schiedt, 293 U.S. 474 (1935), could be cured by the expansion of remittitur review. As this comment will argue, Section II infra, remittitur review in some cases may increase uneasiness regarding the propriety of remittitur. 
noted above, under traditional procedural principles, the Fifth Circuit's position would appear to be more logical than that taken by the Supreme Court; yet it is impossible to choose between these two rules on procedural grounds alone. Rather, constitutional and policy considerations, not raised in the Woodworth opinion, must be taken into account. Before proceeding with that discussion, however, the other side of the reviewability problem-the defendant's attempt to gain review of a refusal to order a remittitur-must be explored.

\section{B. Reviewability of the Refusal to Order a Remittitur}

Problems of finality and waiver do not arise when a trial court refuses the defendant's request to disturb a jury award on the grounds that it is excessive. A dissatisfied defendant in such a case has the opportunity of appealing a final judgment to which he has not consented. Thus, the Woodworth rule presents no obstacle to appellate review of the refusal to order remittitur or retrial. ${ }^{22}$ There is, however, another, more general federal rule that, in the past, operated to bar defendants as well as plaintiffs from seeking appellate review of trial court decisions on such matters.

In Fairmount Glass Works v. Cub Fork Coal Co., ${ }^{23}$ Justice

${ }^{22}$ This fact may help explain why the Fifth Circuit joined its sister circuits in allowing review of the failure to issue remittiturs long before it decided to move beyond the other circuits by also reviewing the issuance of such orders. See Whiteman v. Pitrie, 220 F.2d 914 (5th Cir. 1955). The other cases include Bankers Life \& Casualty Co. v. Kirtley, 307 F.2d 418 (8th Cir. 1962); Dagnello v. Long Island R.R., 297 F.2d 797 (2d Cir. 1961); Ballard v. Forbes, 208 F.2d 883 (1st Cir. 1954); Bucher v. Krause, 200 F.2d 576 (7th Cir. 1952); Trowbridge v. Abrasive Co. of Philadelphia, 190 F.2d 825 (3d Cir. 1951); Smith v. Welch, 189 F.2d 832 (10th Cir. 1951); Sebring Trucking Co. v. White, 187 F.2d 486 (6th Cir. 1951); Boyle v. Bond, 187 F.2d 362 (D.C. Cir. 1951); Virginia Ry. v. Armentrout, 166 F.2d 400 (4th Cir. 1948); Cobb v. Lepisto, 6 F.2d 128 (9th Cir. 1925).

In taking this further step the Fifth Circuit may well have been influenced by considerations of equity between classes of litigants. No matter which party complains, the fact issue in dispute is always the same: the appropriateness of a jury award. It can thus be argued that, since defendants are permitted to challenge the refusal to issue remittitur orders, plaintiffs should have a similar right when the orders are issued against them.

${ }^{23} 287$ U.S. 474 (1933). This case presented a somewhat unusual set of facts. In a diversity action the defendant had won two jury verdicts, both overturned by the appellate court. The tenacious plaintiff was finally victorious in the third trial, but the jury assessed damages of only one dollar. The appellate court reversed again, holding that the verdict was a determination of liability and that clearly inadequate damages had been awarded since the plaintiff was entitled to at least $\$ 18,250$. The Supreme Court reversed again and reinstated the jury verdict, holding that the damage award was not reviewable on grounds of inadequacy. See also Southern Ry. v. Bennett, 233 U.S. 80, 87 (1914); Metropolitan R.R. v. Moor, 121 U.S. $558,574-75$ (1887). It should be noted that the following discussion, while framed for the sake of clarity in terms of the defendant's dissatisfaction with an excessive award, also applies to a plaintiff's dissatisfaction with an inadequate award. The same could not be said of the 
Brandeis described this rule as a prohibition against review of trial court decisions granting or denying motions for new trials when matters of fact were in dispute and noted that it was frequently applied where the issue was whether the damage award was excessive or inadequate. "Settled by a long and unbroken line of decisions," 24 the rule had traditionally been supported by reference to two different policies. First was the prohibition of section 22 of the Judiciary Act of 1789 on appellate court reversals based on errors of fact; this explicit restriction of judicial power could also be "rested on that part of the Seventh Amendment which provides that 'no fact tried by a jury, shall be otherwise re-examined in any court of the United States, than according to the rules of the common law.' "25 A second reason which, according to Justice Brandeis, was more frequently cited was that the decision on the appropriateness of the jury award was a matter committed to the discretion of the trial judge.

Since Fairmount Glass, the trial court's discretion in many matters has become subject to the ever-widening scrutiny of appellate court review. ${ }^{26}$ But the constitutional constraints on judicial power to review facts determined by a jury remain. The precise limits of those constraints is the subject of a long-standing debate, ${ }^{27}$ carried on at two levels, one primarily historical, the other based on policy considerations. On the first level the question is whether and to what extent eighteenth century common law rules were explicitly incorporated in the seventh amendment. On the second level the question is what safeguards are necessary to preserve the integrity of the jury's fact-finding process and thus to secure the constitutional right to jury trial.

Professor Hinton, commenting in 1933 on the Fairmount case, challenged Brandeis's opinion on the first level.$^{28}$ While conceding that under the English common law a litigant would not have been entitled to review of a decision refusing a new trial because of an

preceding section since the unconstitutionality of additur in the federal courts keeps the defendant from ending up in a similar dilemma.

24 Fairmount Glass Works v. Cub Fork Coal Co., 287 U.S. 474, 481 (1933).

${ }^{25}$ Id. at 482.

${ }^{28}$ Wright, The Doubtful Omniscience of Appellate Courts, 41 MnN. L. Rev. 751 (1957).

${ }^{27}$ The most recent opponents in the debate are Professor Moore, who supports an expanded power of appellate review, and Professor Wright, who prefers the more traditional approach. See, e.g., 3 W. Barron \& A. Holtzoff, Federal Practice and Procedure $\$ 1302.1$, at 346, § 1305.1, at 376 (C. Wright ed. 1958); J. Moore, Federal Practice, ๆף 59.05[3], 59.08[6], 59.15[1],[3] (2d ed. 1966); Wright, supra note 26.

${ }^{28}$ Hinton, Power of Federal Appellate Courts to Review Ruling on Motion for New Trial, 1 U. Chi. L. Rev. 111 (1933). 
excessive or inadequate jury award, Hinton argued that the English practice should be disregarded in determining the scope of reviewability in the federal courts. Under English law, a litigant's application for retrial was heard by a bench of four judges, thus obviating, or at least lessening, the need for intervention by a reviewing court. By retaining the prohibition on review in the absence of the safeguard of a court en banc, Hinton argued that the Fairmount Court had showed itself "[u]nable to escape the 'dead hand' of the common law." 29

On the second level, Professor William Wirt Blume ${ }^{30}$ argued that review of a trial court decision granting or denying a new trial is not contrary to the seventh amendment because "the appellate court is reviewing only the decision of the judge-not the verdict of the jury." $\mathrm{He}$ insisted that reexamining the facts tried by the jury "for the purpose of reviewing the decision of the judge" is not forbidden by the seventh amendment. ${ }^{31}$

Recently, Judge Skelly Wright addressed the same issue in an opinion dealing with the proper scope of appellate review of remittitur orders. ${ }^{32} \mathrm{He}$ noted that the traditional prohibition on review of new trial determinations stems not only from respect for the trial judge's "unique opportunity to consider the evidence in the living courtroom context," but also from the deference due "the agency to whom the Constitution allocates the fact-finding function in the first instance-the jury." 33 At least in instances where judge and jury agree, Judge Wright saw little justification for appellate court interference with the result. Despite such considerations, all eleven circuits have now adopted the position advocated by Professors Hinton, Blume, and more recently, Professor Moore; all now hold that the appellate court does have the power to review a trial court's denial of a motion for a new trial on the grounds of inadequate or excessive damages for an abuse of discretion..$^{34}$

In so holding, the courts of appeal have had little Supreme Court encouragement. In the Fairmount case Justice Brandeis provided only a slight opening for reviewability when he explicitly re-

21 Id.

${ }^{30}$ Blume, Review of Facts in Jury Cases-The Seventh Amendment, 20 AM. Jud. Soc'y 130 (1936).

${ }^{31}$ Id. at 131. See also Pound, Principles of Practice Reform, 71 CENT. L.J. 221 (1910), cited by Blume, supra note 30 , at 131.

${ }^{32}$ Taylor v. Washington Terminal Co., 409 F.2d 145 (D.C. Cir.), cert. denied, 396 U.S. 835 (1969).

13 Id. at 148.

31 See cases cited at note 22 supra. 
fused to foreclose the possibility that review of an order granting or denying a motion for a new trial where issues of fact are involved might be appropriate in some other case in the future. ${ }^{35}$ The Court's next statement on the subject after Fairmount was almost an afterthought. In Affolder v. New York C. \& St. L. R.R. ${ }^{36}$ Justice Clark spent four pages discussing the propriety of jury instructions regarding liability. The fact that the trial court also happened to have reduced the plaintiff's award by a remittitur seems to have been viewed by all the participants as incidental to the case, and Justice Clark tossed off what may be an equally incidental, perhaps even offhand remark at the end of the opinion, stating that "the damages awarded by the District Court's judgment is [sic] not monstrous in the circumstances of this case." 37

While this statement might seem tacitly to approve appellate court review of orders denying new trials, the Supreme Court soon made it clear that it was still not prepared to jettison explicitly the traditional rule barring such review. In Neese $v$. Southern $R y .,{ }^{38}$ a per curiam opinion citing neither Fairmount nor Affolder, the Court, in overturning a Fourth Circuit reversal of a district court's remittitur order, commented only as follows: "Even assuming such appellate power to exist under the Seventh Amendment, we find that the Court of Appeals was not justified, on this record, in regarding the denial of a new trial, upon a remittitur of part of the verdict, as an abuse of discretion." 39

More recently, in Grunenthal v. Long Island R.R. ${ }^{40}$ the Court reversed a Second Circuit finding of an abuse of discretion in the refusal to order a remittitur or retrial in an FELA case. The Court thus reinstated a trial court decision to allow a jury verdict to remain undisturbed, just as it had done in Fairmount and in Neese, and, once again, it explicitly refused to rule on whether appellate courts have the power to review such orders or are, as the plaintiff contended, precluded from doing so by the seventh amendment. Instead, Justice Brennan said:

We have no occasion in this case to consider that argument, for assuming, without deciding, that the Court of Appeals was empowered to review the denial and invoked the correct stan-

\footnotetext{
${ }^{35}$ Fairmount Glass Works v. Cub Fork Coal Co., 287 U.S. 474, 485 (1933).

36339 U.S. 96 (1950).

${ }^{37}$ Id. at 101 .

38350 U.S. 77 (1955).

39 Id.

to 393 U.S. 156 (1968).
} 
dard of review, the action of the trial judge, as we view the evidence, should not have been disturbed. ${ }^{41}$

Despite its reiteration of the "assuming without deciding" formula, the Grunenthal Court did treat this case in a new way. Unlike the Fairmount and Neese Courts, the Grunenthal Court made a detailed appraisal of the evidence bearing on damages, finding that the $\$ 150,000$ that the jury had apparently awarded for pain and suffering was not "without support in the record." 42

It is unclear what conclusions, if any, may be drawn from this unusual, detailed consideration by the Supreme Court of the worth of pain and suffering, or from its holding that the appellate court's attempt to set a limit on that value was wrong. In his dissent, Justice Harlan concluded that such matters were not suitable ones for the Court to resolve and that certiorari should have been dismissed as improvidently granted..$^{43}$ Justice Stewart, in a separate dissent, expressed impatience with the majority's continued use of the "assuming without deciding" language and argued that by proceeding to review the district judge's order in the case, the Court had, in effect, decided that "nothing in the Seventh Amendment .. . precludes appellate review of the trial judge's denial of a motion to set aside an award as excessive." 44

After four decades of "assuming without deciding" it seems reasonable to conclude, as the Second Circuit did in Dagnello $v$. Long Island R.R., ${ }^{45}$ that the Court's continuing concern for the seventh amendment is the central factor in its hesitancy to rule decisively on the question of the reviewability of orders denying motions for new trials. Moreover, this problem may well include not only the constitutionality of review but also the constitutionality of remittitur itself. In all three cases on this issue that the Supreme Court has chosen to review, the damage issue was complicated by the presence of an unliquidated damage element for which there was no clear rule of law. ${ }^{46}$ As this comment will argue below, ${ }^{47}$ these are precisely the cases in which remittitur is on its shakiest constitutional basis.

\footnotetext{
"Id. at 158.

12 Id. at 161 .

$13 \mathrm{Id}$. at 163.

"Id. at 164 .

is 289 F.2d 797 (2d Cir. 1961).

"Affolder, Neese, and Grunenthal were all personal injury cases.

${ }^{17}$ See text and notes at notes 64-70 infra.
} 


\section{The Constitutional Question: Fact Determination AND THE SEVENTH AMENDMENT}

A. Dimick v. Schiedt

The Supreme Court has never ruled directly on the constitutionality of remittitur in the federal courts. In Dimick v. Schiedt, ${ }^{48}$ however, the Court held additur (in which the judge offers the defendant a choice between a new trial and the payment of a larger damage award) to be an unconstitutional practice, in violation of the seventh amendment. ${ }^{48}$ But in so holding Justice Sutherland, writing for the majority, seems to many to have implicitly sanctioned the well-established practice of remittitur-even though the propriety of that practice was not at issue in the case..$^{50}$ One paragraph in particular has been quoted again and again by proponents of unlimited remittitur:

Where the verdict is excessive, the practice of substituting a remission of the excess for a new trial is not without plausible support in the view that what remains is included in the verdict along with the unlawful excess, -in that sense that it has been found by the jury,-and that the remittitur has the effect of merely lopping off an excrescence. But where the verdict is too small, an increase by the court is a bald addition of something which in no sense can be said to be included in the verdict. ${ }^{51}$

Shorn of its context, this quotation can and often has been interpreted to mean that Justice Sutherland was firmly convinced of the constitutionality of remittitur and equally firmly convinced of the unconstitutionality of additur, all on the basis of an arbitrary distinction between two practices indistinguishable except insofar as one involves discretionary subtraction and the other discretionary addition. Within the context of the rest of the opinion, however, it is less than an unqualified endorsement of remittitur.

18293 U.S. 474 (1935).

"For a more detailed discussion of the special problems relevant to additur, see Wilson, The Motion for New Trial Based on Inadequacy of Damages Awarded, 39 NEB. L. REv. 694 (1960).

${ }^{30}$ See, e.g., Jehl v. Southern Pac. Co., 66 Cal. 2d 821, 427 P.2d 988, 59 Cal. Rptr. 276 (1967), overruling Dorsey v. Barba, 38 Cal. 2d 530, 240 P.2d 604 (1952). See also James, Remedies for Excessiveness or Inadequacy of Verdicts: New Trial on Some or All Issues, Remmititur and Additur, 1 Duquesne U.L. Rev. 143 (1963); Comment, Statutory Authorization of Additur and Remittur, 43 Miss. L.J. 107 (1972); Note, Civil Procedure-Power of Trial Court to Grant Additur, 40 TENN. L. REv. 753 (1973); Note, Appealability of Rulings on Motion for New Trial in the Federal Courts, 98 U. PA. L. Rev. 575 (1950); Comment, Correction of Damage Verdicts by Remittitur and Additur, 44 YALE L.J. 318 (1934).

s1 Dimick v. Schiedt, 293 U.S. 474, 486 (1935). 
Justice Sutherland expressed grave doubts about the constitutionality of both remittitur and additur but was reluctant to view the former as unconstitutional because there seemed to be a considerable amount of precedent behind it, as contrasted with the minimal support for additur. ${ }^{52}$ Justice Sutherland cited six cases in which the Supreme Court appeared to have sanctioned remittitur..$^{53}$ Besides Supreme Court precedent, however, he also had to consider "the rules of the common law" as of 1791, which are explicitly incorporated by the seventh amendment.

In canvassing the English precedents, Justice Sutherland found that the practice of remittitur had been "condemned as opposed to the principles of the common law by every reasoned English decision, both before and after the adoption of the Federal Constitution . . . ." Nonetheless, he was unable to overcome his reluctance to do what he thought would be necessary to bring American practice into accord with the common law of 1791: overrule all of the Supreme Court and lower court cases that seemed to approve the practice. Accordingly, he made an uneasy compromise, declaring additur unconstitutional but giving remittitur his begrudging approval.

In his much-quoted dissent in Dimick, Justice Stone ridiculed Justice Sutherland's struggle to deal with the common law prior to 1791 as an attempt "to perpetuate in changeless form the minutiae of trial practice as it existed in the English courts in 1791." ${ }^{55}$ Professor Edith Henderson more recently derided similar attempts on the

\footnotetext{
$32[1] \mathrm{t}$, therefore, may be that if the question of remittitur were now before us for the first time, it would be decided otherwise. But, first announced by Mr. Justice Story in 1822, the doctrine has been accepted as the law for more than a hundred years and uniformly applied in the federal courts during that time. And, as it finds some support in the practice of the English courts prior to the adoption of the Constitution, we may assume that in a case involving a remittitur, which this case does not, the doctrine would not be reconsidered or disturbed at this late day.

Nevertheless, this court in a very special sense is charged with the duty of construing and upholding the Constitution; and in the discharge of that important duty, it ever must be alert to see that a doubtful precedent be not extended by mere analogy to a different case if the result will be to weaken or subvert what it conceives to be a principle of the fundamental law of the land.
}

Id. at 484-85.

3s Justice Story initially authorized the practice of remittitur while sitting on circuit. Blunt v. Little, 3 F. Cas. 760 (No. 1578) (C.C.D. Mass. 1822).

The six cases are: Gila Valley G. \& N. Ry. v. Hall, 232 U.S. 94 (1914); German Alliance Ins. Co. v. Hale, 219 U.S. 307 (1911); Koenigsberger v. Richmond Silver Mining Co., 158 U.S. 41, 52 (1895); Kennon v. Gilmer, 131 U.S. 22 (1889); Arkansas Valley Land \& Cattle Co. v. Mann, 130 U.S. 69 (1889); Northern Pac. R.R. v. Herbert, 116 U.S. 642 (1886).

s1 Dimick v. Schiedt, 293 U.S. 474, 484 (1935).

ss Id. at 490 . 
grounds that "the amendment was not intended to codify a rigid form of jury practice-that indeed there was no consistent practice in 1790 to be codified." 56

Whether or not there was a consistent practice in the eighteenth century should be, for all practical purposes, irrelevant. The important point would seem to be whether there was a consistent principle behind the multiplicity of practices. Justice Sutherland concluded that there was and expressed it in the following manner:

The controlling distinction between the power of the court and that of the jury is that the former is the power to determine the law and the latter to determine the facts. In dealing with questions like the one now under consideration, that distinction must be borne steadily in mind. ${ }^{57}$

A wide variety of federal trial court practices may be consistent with this overriding principle; a few, like the issuance of remittitur orders in some types of cases, may not be..$^{58}$ That, at any rate, seems to be the essence of the problem, and proponents of unlimited remittitur have generally failed to meet it squarely on the merits.

Instead of arguing on the basis of seventh amendment principles, proponents of unlimited remittitur have focused on its advantages in terms of efficiency, stressing the growing need for a means of expediting the work of the federal courts. ${ }^{9}$ In addition, they have argued that any trial court abuses of the remittitur procedure could be corrected through liberalized provisions for appellate review. However persuasive these arguments may be, ${ }^{60}$ the constitutional question remains; unfortunately, the proponents of unlimited remittitur and expanded remittitur review have not dealt as convincingly with this issue.

Justice Stone's argument in Dimick in support of unlimited remittitur is perhaps typical: he stated that the seventh amendment "is concerned with substance and not with form" and guarantees only "the essentials" of trial by jury. ${ }^{61}$ Consequently, there is no need for a "search of the legal scrap heap of a century and a half

${ }^{56}$ Henderson, The Background of the Seventh Amendment, 80 HARv. L. REv. 289, 337 (1966).

${ }^{37}$ Dimick v. Schiedt, 293 U.S. 474,486 (1935).

58 See text and notes at notes 64-70 infra.

${ }^{59}$ E.g., Dimick v. Schiedt, 293 U.S. 474, 489 (Stone, J., dissenting); Jehl v. Southern Pac. Co., 66 Cal. 2d 821, 427 P.2d 988, 59 Cal. Rptr. 276 (1967) (Traynor, J.). 86 infra.

${ }^{\text {so }}$ In some instances this argument may be singularly unpersuasive. See text at notes $84-$

i1 Dimick v. Schiedt, 293 U.S. 474,490 (1935). 
ago" 62 and no inconsistency in allowing judges to correct jury damage awards when they are outside "the legal limits of a proper verdict." 63

There are substantial problems with this argument. It would seem that in a civil case a jury determination of the quantum of damages $i s$ the very essence or substance of the right to trial by jury. If this is so, then the whole argument turns on the "legal limits of a proper verdict" notion, and the problem becomes one of deciding how a judge may determine what those limits are, when they have been exceeded, and by how much. Justice Stone argued forcefully that judges can and should be allowed to perform this task, but he did not explain how they should do so, even though the case before him presented that question in its most acute form by virtue of the fact that it was a personal injury case involving the assessment of the worth of pain and suffering.

In the years since Dimick, the practice of remittitur in such cases has posed particularly difficult problems for the federal judiciary. Section III of this comment will focus on the adequacy of the federal courts' response. Before going on to that topic, however, the comment examines some of the English principles and American precedents referred to in Dimick, to see whether they might not offer more guidance in determining the propriety of remittitur than was at first apparent.

B. English Principles and American Precedent Reconsidered: A Possible Reconciliation

In Dimick, as in American cases and commentaries generally, with a few notable exceptions, ${ }^{64}$ remittitur tends to be treated as a unitary concept, as if it were necessary to accept the practice in all cases where it might be applied or to reject it totally. The English sources cited by Justice Sutherland give quite a different impression, drawing a sharp distinction between cases involving liquidated damages and those involving unliquidated claims. For example, Mayne's Treatise on Damages was quoted as stating that "it was always admitted 'that in cases where the amount of damages was uncertain their assessment was a matter so peculiarly within the province of the jury that the Court should not alter it." " 65

12 Id. at 495 .

"Id. at 492 .

" Carlin, Remittiturs and Additurs, 49 W. VA. L.Q. 1 (1942); Wright, supra note 26, at 752.

is Dimick v. Schiedt, 293 U.S. 474, $479-80$ (1935). See also J. MAyne, Treatise on 
This frequently ignored distinction seems peculiarly relevant to the conflict Justice Sutherland perceived between principle and precedent in American law because it parallels the distinction between disputed facts, which it is the right and duty of the jury to determine, and undisputed facts, which neither judge nor jury is at liberty to disregard. Thus, it seems perfectly consistent with the seventh amendment to allow the federal judiciary to correct jury verdicts that fly in the face of undisputed facts; it does not seem consistent to allow the discretionary substitution of judicial conclusions about disputed facts for jury conclusions about such facts. The logic of this position would allow the continuance of the practice of remittitur but would limit its scope to cases involving liquidated damages and/or to cases where some clear rule of law applies. By thus limiting the scope of remittitur, it would seem possible to retain whatever efficiency advantages the practice offers without in any way curtailing rights guaranteed by the seventh amendment.

Moreover, such a distinction would not necessitate the overruling of the many early Supreme Court cases that seem to authorize remittitur. ${ }^{66}$ Of the eight cases noted above, ${ }^{67}$ four involved review of state or territorial law claims decided by state or territorial $\operatorname{courts}^{68}$ and would thus seem to pose no problem, since the seventh amendment is binding only on the federal courts. The other four cases cited all involved federal court remittitur orders, but two of them were issued in property cases $^{69}$ and the other two in contract cases, ${ }^{70}$ areas where damages are frequently liquidated and where there are reasonably clear rules of law regarding the determination of unliquidated damages. Not one of these cases involved the issuance of remittitur orders by a federal court in a personal injury case or in any other type of unliquidated damage case in which no clear rule of law applies.

To this point at least there have been no limitations imposed

Damages 571 (9th ed. 1920) (1st ed. 1856); J. SAYER, LAW of Damages 177 (1790); Beardmore v. Carrington, 2 Wils. K.B. 244, 95 Eng. Rep. 790 (K.B. 1764).

" Limiting remittitur in this way would, however, necessitate overruling many lower court decisions. Justice Sutherland noted that remittitur "has been uniformly practiced by the lower federal courts." 293 U.S. at 483.

67 See note 1 supra.

os Union Pac. R.R. v. Hadley, 246 U.S. 330 (1918); Gila Valley G. \& N. Ry. v. Hall, 232 U.S. 94 (1914); Tevis v. Ryan, 233 U.S. 273 (1914); Northern Pac. R.R. v. Herbert, 116 U.S. 642 (1886).

6 Arkansas Valley Land \& Cattle Co. v. Mann, 130 U.S. 397 (1896); Clark v. Sidway, 142 U.S. 682 (1892).

${ }^{70}$ German Alliance Ins. Co. v. Hale, 219 U.S. 307 (1911); Hansen v. Boyd, 161 U.S. 397 (1896). 
on the types of cases in which remittitur is appropriate; concern about such unrestricted use of remittitur has perhaps accelerated the trend toward expanded appellate review. This trend has, in turn, forced appellate courts to struggle to develop standards applicable to the practice of remittitur in all types of cases. A consideration of those standards and of the problems in applying them to unliquidated damage cases where no clear rules of law apply follows.

\section{STANDARDS FOR REVIEW}

\section{A. The Purposes of Review}

The main rationale for remittitur is the promotion of efficiency. Yet those who support the practice on this basis clearly do not wish to compromise justice in the interest of efficiency. For that reason, many of the strongest proponents of remittitur also favor making trial court remittitur decisions reviewable..$^{71}$ In this way, they hope to decrease the danger that arbitrary or ill-considered action by a single judge, amounting to an abuse of his discretion, will remain uncorrected.

One may hope, moreover, that allowing review will serve to improve justice by increasing consistency across cases litigated in different trial courts, in accord with the ideal that like cases should be treated alike. Still a third argument favoring review is the hope that it will serve as a check on the ever-present danger of infringement on seventh amendment rights. Even though proponents of unlimited remittitur may at times downgrade the importance of the seventh amendment argument, none favor allowing the substitution of a judicial opinion for a jury opinion on a matter of disputed fact over which reasonable men might disagree merely because a jury's answer is at variance with a judge's personal calculations.

The assumption underlying all these arguments is that the appellate courts are capable of fashioning a workable standard for testing the trial judge's exercise of discretion-remittitur review cannot be an efficient process unless the reviewing court can construct a yardstick for determining when an award is excessive and for calculating the amount of that excess. The difficulty of this task varies from case to case. Where damages are liquidated, as they often are in cases involving property damage, no insuperable obsta-

7 Justice Stone, for example, favored liberalized review. See Dimick v. Schiedt, 293 U.S. 474, 489 (1935). See also Jehl v. Southern Pac. Co., 66 Cal. 2d 821, 427 P.2d 988, 59 Cal. Rptr. 276 (1967) (Justice Traynor's remarks). 
cles are likely to present themselves. Even when dealing with unliquidated damage cases of certain types, for example, those that frequently arise in contract actions, the problem can usually be resolved by reference to a body of rules evolved out of long experience. ${ }^{72}$ Admittedly, the application of these rules does not often result in a single correct numerical answer, but the process will normally allow one to establish a correct numerical range for each case, a range with a reasonably clear upper and lower limit. In unliquidated damage cases where no clear rule of law applies, the problem is much more difficult; these difficulties occur in their most acute form in personal injury cases where the defendant and, perhaps also the trial judge, feels that the jury has responded overgenerously to the plaintiff's pain and suffering.

The following section will detail the Fifth Circuit's handling of the problem of setting standards for review. Then the focus will shift to an analysis of problems left unresolved by the Fifth Circuit's approach, as illustrated by a particular case: Gorsalitz v. Olin Mathieson Chemical Corp. ${ }^{73}$

\section{B. The Maximum Recovery Rule}

In its first encounter with the Gorsaltiz case in 1970, the Fifth Circuit worked out the basics of its approach to the problem of standards for remittitur review, an approach which it has since followed in a number of other cases. ${ }^{74}$ The court held that two questions may properly be the subject of review: first, whether the trial court erred in requiring or failing to require any remittitur at all, and, second, assuming that the trial court was correct in requiring some remittitur, whether it erred in determining the amount to be remitted..$^{75}$

In answering both questions, the Fifth Circuit has had recourse to a single standard: the maximum recovery rule. Under this standard remittitur is proper only when a jury exceeds the maximum amount it might reasonably have awarded; the amount to be remitted is proper only insofar as it reduces a jury award to that maximum figure. The underlying theory here is that the jury, by its

${ }^{2}$ See, e.g., Glazer v. Glazer, 278 F. Supp. 476 (E.D. La. 1968).

${ }^{73}$ Gorsalitz v. Olin Mathieson Chem. Corp., 429 F.2d 1033 (5th Cir. 1970), and the rehearing of that case 456 F.2d 180 (5th Cir.), cert. denied, 407 U.S. 921 (1972).

"See, e.g., Bonura v. Sea Land Serv. Inc., 505 F.2d 665 (5th Cir. 1974); Jenkins v. Aquatic Contractors \& Eng'rs, 446 F.2d 520, 522 (5th Cir. 1971).

${ }^{75} 429 \mathrm{~F} .2 \mathrm{~d}$ at 1046. 
excessive verdict, intended to award the maximum allowable, and the defendant therefore has no legitimate grounds to complain against any verdict within the allowable limits.

In making this choice, the Fifth Circuit rejected two competing standards accepted by several state courts. One of these standards requires reduction of an excessive verdict to the minimum amount that the jury might have awarded, on the theory that an award of any greater sum deprives the defendant of his right to a retrial. ${ }^{76}$ The other standard allows the judge to reduce the verdict to whatever amount the court itself feels the jury should have awarded. ${ }^{77}$ In explaining why it rejected these two possibilities and chose the maximum recovery standard instead, the Gorsalitz court quoted Professor Wright to the effect that this is "the only theory which has any reasonable claim of being consistent with the Seventh Amendment." 78

Agreement on the use of the maximum recovery standard is widespread and growing, at least in the federal courts; ${ }^{79}$ in the abstract, it seems a satisfactory one. Problems emerge, however, when the practical question of how the maximum is to be determined is raised. In a contract case like Glazer v. Glazer, ${ }^{80}$ the application of reasonably clear rules of law establishes the numerical range appropriate to the facts of the case, and the maximum recovery rule makes it apparent that the correct figure is the one at the top of the range. But in a personal injury case like Gorsalitz, establishing a

"See, e.g., Meissner v. Pupas, 35 F. Supp. 676, (E.D. Wis. 1940), aff'd, 124 F.2d 720 (7th Cir. 1941); Swanson v. Schultz, 223 Wis. 278, 284, 270 N.W. 43, 45 (1936); Reykdal v. Miller, 216 Wis. 561, 257 N.W. 604 (1934); 270 N.W. 43, 45 (1936); Lehner v. Kelley, 215 Wis. 265, 254 N.W. 634 (1934).

"See, e.g., Jehl v. Southern Pac. Co., 66 Cal. 2d 821, 832-33, 427 P.2d 988, 995, 59 Cal. Rptr. 276, 283 (1967). Justice Traynor, after concluding that "[t]here is no essential difference between the procedures appropriate for remittitur and additur, and we may therefore look to remittitur cases to determine the proper procedure for additur," continues as follows:

If the court decides to order an additur, it should set the amount that it determines from the evidence to be fair and reasonable. In this respect it should exercise its completely independent judgment. It need not fix . . . the minimum or maximum amount that would be supported by substantial evidence and therefore sustainable on appeal.

Justice Traynor, it should be noted, was interpreting the right-to-jury trial provision of the California constitution, which, he observed, differs substantially from the seventh amendment in the United States Constitution. See also 6A J. MoorE, supra note 27, 79.05 [3], at $59-57,59-58$ (2d ed. 1973).

7s Gorsalitz v. Olin Mathieson Chem. Corp., 429 F.2d 1033, 1046-47 (5th Cir. 1970), quoting $3 \mathrm{~W}$. Barron \& A. HoLtzofF, supra note 27, \& 1305.1, at 276 (C. Wright ed. 1958). See also F. JAMEs, Civil Procedure 326 (1965) (who comments that any other practice "seems to be a clear invasion of the jury's sphere.").

"See, e.g., Manning v. Altec, Inc., 488 F.2d 127 (6th Cir. 1973); Taylor v. Washington Terminal Co., 409 F.2d 145 (D.C. Cir.), cert. denied, 396 U.S. 835 (1969).

sa 278 F. Supp. 476 (E.D. La. 1968). 
proper range for the worth of pain and suffering is necessarily a difficult undertaking in which vague feelings are often relied upon in place of numerical calculations. For example, in Gorsalitz the court makes reference to cases in which the "verdict is so unreasonably high as to result in a miscarriage of justice" and to verdicts that are "so inordinately large as obviously to exceed the maximum limit of a reasonable range within which the jury may properly operate."81 Other courts have tried to describe the amount that exceeds the allowable maximum by talking about verdicts that are "gross," "monstrous," "outrageous," and/or "shocking to the conscience of the court." 82

It is questionable whether an actual measuring rod can be constructed for the latter type of cases; it may be that judicial corrections of jury awards in this area can only reflect the personal predictions of particular judges or groups of judges ${ }^{83}$ Looking solely at the judges' statements, one searches in vain for straight-forward accounts of what they are doing. However, close analysis of the actual computation of amounts in these cases suggests that there

${ }^{81}$ Gorsalitz v. Olin Mathieson Chemical Corp., 429 F.2d 1033, 1046 (5th Cir. 1970).

${ }^{82}$ One or more of these words and phrases have been used in the following illustrative but not exhaustive list of cases: Century " 21 "' Shows v. Owens, 400 F.2d 603 (8th Cir. 1968); Massachusetts Bonding \& Ins. Co. v. Abbott, 287 F.2d 547 (5th Cir. 1961); Russell v. Monongahela Ry., 262 F.2d 349, 352 (3d Cir. 1958); Ballard v. Forbes, 208 F.2d 883, 888 (1st Cir. 1954); United States v. Grigalauskas, 195 F.2d 494, 498 (1st Cir. 1952); Trowbridge v. Abrasive Co. of Philadelphia, 190 F.2d 825, 830 (3d Cir. 1951); Sunray Oil Corp. v. Allbritton, 188 F.2d 751 (5th Cir. 1951); Covey Gas \& Oil Co v. Checketts, 187 F.2d 561, 563 (9th Cir. 1951); Southern Pac. Co. v. Guthrie, 186 F.2d 926 (9th Cir. 1951).

State courts have added adjectives but not clarity to this list, e.g., "manifestly excessive" has been popular in Ohio and Illinois, Toledo, C. \& O.R.R. v. Miller, 108 Ohio St. 388, 140 N.E. 617 (1923); Collins v. Sanitary Dist., 270 IIl. 108, 110 N.E. 318 (1915), while "grossly excessive" seems to be the preferred term in Missouri. Erny v. Revlon Inc., 459 S.W.2d 261 (Mo. 1970); Helming v. Dulle, 441 S.W.2d 351 (Mo. 1969).

An Oregon justice contributed what is probably the most colorful phrase when he described the jury award in Van Lom v. Schneiderman, 187 Ore. 89, 210 P.2d 461 (1949), as "impregnated with evil," apparently because the jury assessed punitive damages equal in amount to compensatory ones in an assault case. See Lusk, Forty-five Years of Article VII, Section 3, Constitution of Oregon, 35 ORE. L. Rev. 1, 9 (1955). Yet even Justice Lusk, a strong supporter of unlimited remittitur, acknowledged the difficulty of making such judgments. In Rust v. Moore-McCormick Lines, Inc., 180 Ore. 409, 435-36; 117 P.2d 429, 441 (1947), he said: "It is difficult to define the circumstances which warrant exercise of the power [to set aside excessive verdicts], and we shall not attempt to do so." Another commentator put it more bluntly: "Thus, we are in the process of arriving at a disturbing conclusion that there is no sound principle of determining 'excessive' verdicts.' Nardi, Excessive Personal Injury Awards, 1 Clev.-Mar. L. Rev. 23, 33 n.26 (1952).

${ }^{83}$ See Carlin, supra note 64; Hullverson, Remittitur and Other Things, 28 Mo. B.J. 81 (1972); Nardi, supra note 82; Tongue, In Defense of Juries as Exclusive Judges of the Facts, 35 Ore. L. Rev. 143, 188 (1956). See also Note, Constitutional Law-Right to Jury Trial-Judicial Use of Additurs in Correcting Insufficient Damage Verdicts, 21 VA. L. Rev. 666,676 (1935). 
may be an implicit measuring rod and some tacit agreement about its use. Yet, as the examination of the Gorsalitz case in the next subsection will demonstrate, use of such an unstated measure poses substantial problems of fairness.

\section{How the Maximum Is Determined in a Concrete Case: Gorsalitz}

Plaintiff Gorsalitz sued for damages for "extremely severe personal injuries" sustained while working with electrical equipment on the defendant chemical corporation's premises. ${ }^{84}$ The jury decided the liability issue in plaintiff's favor and awarded him $\$ 1,380,000$. Defendant, still contesting the liability issue, moved for j.n.o.v. and, in the alternative, for a new trial. The district court judge, finding no fault with the jury's conclusion on liability, rejected the j.n.o.v. motion but denied the new trial motion only on the condition that plaintiff agree to remit $\$ 689,367$, cutting his recovery to $\$ 690,633$, barely half of the original award.

Both litigants appealed, and the Fifth Circuit upheld the finding of liability as well as the trial court's decision that the jury's award had exceeded the allowable maximum and that some remittitur was therefore appropriate. However, it concluded that the trial court had failed to use the maximum recovery rule in fixing the amount of the remittitur, but instead had substituted its own determination of what was reasonable. Accordingly, it affirmed in part, vacated in part, and remanded for a redetermination of the amount of the remittitur. On remand, the remittitur was reduced to $\$ 492,971$, thus increasing the award to $\$ 887,029$. The plaintiff appealed a second time and the appellate court once more reduced the remittitur, but this time by only $\$ 2,737$, increasing the fourth and final award to $\$ 889,766$.

At first glance, these figures would seem to raise more questions than they answer. How did the appellate court decide that the original jury award in this case significantly overshot the allowable maximum and that the trial court's first remittitur order significantly undershot that mysterious mark, whereas its second remittitur order was almost, but not quite, on target? The court recounts in some detail its method of computing lost wages to correct the second order by two thousand dollars, ${ }^{85}$ but neither lost wages nor medical expenses account for the enormous shifts of many hundreds of thou-

st Gorsalitz v. Olin Mathieson Chemical Corp., 429 F.2d 1033, 1035 (5th Cir. 1970).

xs Gorsalitz v. Olin Mathieson Chemical Corp., 456 F.2d 180, 181 (5th Cir.), cert. denied, 407 U.S. 921 (1972). 
sands of dollars in the Gorsalitz award.

The big shifts have to do with the amounts awarded for pain and suffering, and here, to say the least, the court is cryptic. All that can be gleaned with certainty is this: all three of the official figuresetters, the jury, the trial court and the appellate court, were in essential agreement that past and future lost wages slightly exceeded $\$ 200,000$, while past and future medical expenses fell somewhat short of $\$ 200,000$, making a total of approximately $\$ 400,000$. All three disagreed sharply on the value of pain and suffering: the jury thought it was worth $\$ 800,000$, the trial court first thought it was worth only $\$ 200,000$, but when compelled to reconsider, valued it at about $\$ 400,000$. The appellate court rejected both the original jury evaluation and the initial trial court evaluation and, in effect, accepted the trial court's second approximation of the worth of pain and suffering.

In valuing pain and suffering, the jury could have been saying that it was not limited to the value of either medical expenses or lost wages and that it could, when suffering was severe enough, exceed the combined total of both. The trial court judge initially seems to have thought that pain and suffering damages could equal but not exceed the medical expenses occasioned by the injury. The appellate court rejected both views and accepted a correction that set the worth of pain and suffering at an amount roughly equal to but not in excess of the combined total of medical expenses and lost wages. If the Fifth Circuit had meant to create a standard for determining the maximum recovery for pain and suffering based on a numerical relationship to certain other definable categories of damages it would not have been difficult for it to say so clearly and simply, without reliance on adjectives of dubious import. If this were done, trial court judges would no longer need to struggle with what one judge has described as "a Solomonic task" frequent reversals. Instead, they could simply instruct juries that they were free to award any amount they thought appropriate for pain and suffering up to but not in excess of the combined total of special damages in any personal injury case, perhaps using a similar rule regarding general damages in some other types of cases as well.

Such a standard would certainly increase clarity in an undeniably murky area, but it would foster the ideal of consistency only in an abstract mathematical sense. As between individual litigants, it would effectively destroy that ideal and the related ideal of equality 
under the law because it would make the value of pain and suffering dependent upon the sufferer's salary. The implied standard is thus unacceptable; perhaps for this reason it has remained unarticulated.

\section{New Trial Orders in Unliquidated Damage Cases}

Over the last several decades there has been a great expansion in trial court discretion in the name of flexibility and efficiency. This trend has created a complementary need to expand the scope of judicial review in order to minimize the danger of inconsistent or arbitrary results. ${ }^{87}$ The growth of remittitur review, particularly review of the denial of new trial motions, is one manifestation of this change. In moving in this direction, with the only authority being minor hints or a long silence from the Supreme Court, the courts of appeals seem to be concerned primarily with increasing consistency across cases and ensuring faimess in individual cases. It seems reasonable to assume that a third motive for this movement is the desire to preserve the seventh amendment guarantee of a properly functioning jury that is properly aided in reaching a lawful and appropriate judgment in each case. ${ }^{88}$ As noted above, however, where remittitur itself is improperly, and perhaps unconstitutionally, applied (as to unliquidated damages such as pain and suffering), appellate review may only add to unfairness and inconsistency, without remedying trial court invasions of the jury's function.

Thus, a paradox emerges: remittitur was used instead of retrial in the interest of efficiency, but without review, the risk that it would produce injustice was too high. With review, remittitur may, as in the Gorsalitz case, become an inefficient process, and the superiority of the justice produced thereby is open to serious question. In a case where there are no standards to guide the award, "review" is merely the substitution of the subjective opinion of some judges for the equally subjective opinion of another judge, the only clear superiority of the former over the latter being the purely hierarchical one inherent in the structure of the federal judiciary. ${ }^{89}$

${ }^{87}$ See Wright, supra note 26.

ss The strongest case for appellate court intervention, of course, is the issuance of remittitur where the jury has determined a level of damages and the trial court seeks to cut that level back. See Taylor v. Washington Terminal Co., 409 F.2d 145 (D.C. Cir.), cert. denied, 396 U.S. 835 (1969).

" The history of the Gorsalitz case would belie a recent suggestion that "the simplicity of the issues involved" and the "clear-cut" standard provided by the maximum recovery rule will make it easy for circuit courts to deal with appeals against remittiturs and possible for 
Under these circumstances, the safest and most constitutionally appropriate guide would seem to be reliance, wherever possible, on the judgment of the community as a whole. Of course, a single jury is not an infallible index of community consensus. There may, in fact, be no community consensus on a particular issue, and, even when there is, a particular panel of twelve may turn out to be atypical and unrepresentative..$^{90}$ When a judge fears that the latter circumstance has occurred, it is not unreasonable to allow him the discretion to give a dissatisfied litigant a second chance by granting a request for a new trial and impanelling a new jury. It also seems reasonable to allow an appellate court some power of review over the reasonableness of the trial judge's fears.

At first glance, this argument may seem to raise the specter of the retrial treadmill. Such need not be the case if one recognizes that where a second jury reaches essentially the same conclusion as the first, the odds that there is no community consensus or that both juries are atypical and unrepresentative of community standards are infinitely lower-too low, in fact, to require consideration. Hence, it would seem that there should never be a third trial in such cases. ${ }^{91}$ Two juries that arrive at similar conclusions in the same case provide a clear indication of community consensus, a consensus that should be honored so long as it does not conflict with an articulated rule of law. ${ }^{92}$ Although the second award will probably differ

them to dispose of many of these appeals "by a per curiam opinion or no opinion at all, with relatively little expenditure of judicial time." See Duke Note, supra note 9, at 1162.

${ }^{90}$ This possibility would be heightened if a single, eccentric juror were to dominate the decision-making process. However, empirical research makes this possibility appear quite remote. See H. Kalven \& H. Zeised, The American JuRy 462 (1971).

"In principle, at least, there is no constitutional obstacle to such a limitation. See Louisville \& Nashville R.R. v. Woodson, 134 U.S. 614, 623 (1890), where the Supreme Court upheld the validity of a Tennessee statute forbidding the granting of more than two new trials in the same cause on the facts, noting that

[c]ourts rarely grant a new trial after two verdicts upon the facts in favor of the same party, except for error of law, and the Statute, in the interest of the termination of litigation, makes that imperative which would otherwise be discretionary. . . . We can perceive nothing in the Statute thus applied which amounts to an arbitrary deprivation of the rights of the citizen, and concur with the Supreme Court of Tennessee that this Act, which had been in force more than sixty years before the adoption of the Fourteenth Amendment, was not invalidated by it, while the Fifth Amendment had no application whatever.

Such a limitation may also help to encourage private settlements: since both parties to the litigation would know that the second jury verdict on the facts would be final, neither would be as likely to demand retrial lightly. Conversely, knowing that he may have an unlimited number of chances to score an extreme victory over the other party may encourage a grimly determined plaintiff or defendant to reject all reasonable settlement possibilities, thus increasing the burden on the courts as well as on the other litigant in such a case.

${ }^{92}$ Recent re-emphasis on the desirability of judicial detachment and restraint may be 
from the first to some extent, neither party has grounds for complaint since, by definition, the second award falls within the range of reasonable jury awards.

Suppose, though, that the second jury award differs from the first; that it is not merely a bit higher or lower but significantly above or below the first. Can it still be said to reflect the conscience of the community? Here, the problem becomes more complex because, logically, there are three possible explanations for the divergence of the two juries: (1) it may accurately reflect the division and lack of consensus in society on a particular issue, or (2) it may be a function of the atypicality of the first jury, or (3) it may be a function of the atypicality of the second jury.

The first of these possibilities has the highest probability of being true because the odds that a consensus reached by any fairly selected panel of twelve jurors represents an atypical judgment are low-that is the very assumption on which the jury system is based. Thus, both juries are probably representative, and the divergence between them is likely to be an accurate reflection of a lack of consensus in society, a division foreshadowed by the initial disagreement between judge and jury that caused the judge to order a second trial. This being the case, no purpose would be served by burdening the judiciary and the litigants with further trials only to obtain further discrepant results.

If we assume, however, that a consensus does exist in society and that one of the two juries therefore was atypical, a third trial might indicate which of the two awards was the representative one. The probability that the third award will come out reasonably close to whichever is the "typical" award depends on the degree of consensus in the society. Where there is little consensus, a third trial would be little help in constructing a range within which the majority of awards would fall-by definition, the "reasonable" range of awards; three trials would be far too small a sampling to yield a statistically reliable result.

In personal injury cases where the unliquidated damage element of pain and suffering arises, there is usually little, if any, consensus in society. If there were such a consensus, it would be reasonable to expect it to be expressed in an articulable standard for calculating damages; serious disagreement between judges and jury and between trial and appellate judges, such as that in the

relevant in this context. See, e.g., Kurland, The Appointment and Disappointment of Supreme Court Justices, 2 LAw \& Soc. ORDER 183 (1972). 
Gorsalitz case, would be wholly unexpected. Under these circumstances, holding a third new trial, in order to find the "right" award, would be fruitless.

\section{ConcLusion}

As this comment has argued, remittitur and remittitur review should not be dealt with in a unitary fashion, to be applied to all cases or to none. Rather, to retain the efficiency advantages of remittitur while preserving the parties' seventh amendment rights, it is necessary to distinguish between those cases in which there are liquidated damages or where clear rules of law apply and those cases, typically personal injury cases, in which damages are unliquidated and no standard exists for measuring them. In the first type of case, where damages are liquidated or clear rules of law apply, ordering a conditional remittitur seems fully consistent with the seventh amendment because what is being examined is a question of law and not of fact. Here, there seems to be no constitutional obstacle to review of either a remittitur accepted under protest or the refusal to order remittitur or retrial. Existing procedural obstacles to these practices seem less than compelling, in logic and in practice, and should be abolished. In the second type of case, where damages are unliquidated and no clear rules of law apply, this comment has argued that remittitur is an unconstitutional practice. The trial judge would retain his discretion to order a new trial when he suspected that an award was excessive. The comment has suggested, however, that the judge should limit himself to ordering only one retrial, since a third trial would not improve the quality of the result, but would increase the inefficiency of the system. Following the final judgment rule, this new trial determination would be reviewable for an abuse of discretion after a final judgment had been rendered in the second trial. 